TAHKIM, Jurnal Peradaban dan Hukum Islam. Vol.4 No.l (Maret, 2021) | ISSN : 2597-7962

\title{
EEKTIVITAS UNDANG UNDANG NOMOR 16 TAHUN 2019 TENTANG PERKAWINAN DALAM MEMINIMALISIR PROBLEMATIKA PERKAWINAN
}

\author{
Zaenudin \\ Universitas Selamat Sri \\ zaenpanza@gmail.com
}

\begin{abstract}
ABSTRAK
Sudah lebih dari satu tahun revisi undang-undang perkawinan disahkan. Adanya revisi tersebut diharapkan untuk dapat meminimalisir problematika perkawinan di Indonesia. Penelitian ini bertujuan untuk mengetahui sejauh mana efektivitas undangundang nomor 16 tahun 2019 tentang perkawinan dalam meminimalisir problematika perkawinan. Teori yang digunakan dalam penelitian ini yaitu efektifitas hukum dari Soerjono soekanto bahwa suatu efektifitas hukum dipengaruhi oleh beberapa aspek di antaranya aturannya sendiri, penegak hukum, fasilitas, masyarakat dan budaya. Kesimpulan dari penelitian ini adalah Efektifitas Undang -undang nomor 16 tahun 2019 tentang perkawinan belumlah efektif. Hal ini terbukti dengan meningkatnya jumlah kasus perkawinan setiap tahunnya seperti nikah usia muda, poligami sampai dengan KDRT. Oleh karena itu perlu adanya pembaruan secara komprehensif peraturan perkawinan yang sesuai dengan kekinian dan kesinian.
\end{abstract}

Kata Kunci :Efektifitas, Problematika, Perkawinan

\begin{abstract}
It has been more than one year since the revision of the marriage law was passed. The revision is expected to be able to minimize the problems of marriage in Indonesia. This study aims to determine the extent to which the effectiveness of Law number 16 of 2019 concerning marriage in minimizing marriage problems. The theory used in this study is the effectiveness of law from Soerjono Soekanto that a law effectiveness is influenced by several aspects including the rules themselves, law enforcement, facilities, society and culture. The conclusion of this study is that the effectiveness of Law number 16 of 2019 concerning marriage is not yet effective. This is evidenced by the increasing number of cases of marriage each year such as marriage at a young age, polygamy to domestic violence. Therefore, it is necessary to have a comprehensive reform of the marriage regulations in accordance with the present and the present.
\end{abstract}

Keywords : Effectiveness, Problematics, Marriage 
TAHKIM, Jurnal Peradaban dan Hukum Islam. Vol.4 No.l (Maret, 202I) | ISSN : 2597-7962

\section{A. PENDAHULUAN}

Keluarga adalah miniatur terkecil dalam sebuah bangsa dan Negara. Hal ini disebabkan karena keluarga terdapat pada setiap lapisan masyarakat yang bersifat universal. Terbetuknya keluarga karena adanya pernikahan yang bertujuan membentuk sebuah keluarga berdasarkan peraturan agama dan Negara. Di era millenium keluarga adalah lembaga sosial yang terdepan diterpa arus modernisme seperti individualistis, materialistis, hedonisme yang menbuat hubungan anggota keluarga menjadi renggang. Dalam upaya perlindungan dan pemeliharaan kebahagian dan kesejahteraan masyarakat maka disusunlah Undang-undang Nomor 16 Tahun 2019 revisi dari Undang-undang Nomor 1 Tahun 1974 tentang Perkawinan (Selanjutnya disebut peraturan perkawinan). ${ }^{1}$

Dalam sejarah peraaturan perkawinan di Indonesia selalu melibatkan tiga kepentingan yaitu agama, Negara dan perempuan. Kepentingan Agama keluarga merupakan aspek terkecil sebagai implementasi nilai-nilai yang ada di dalamnya. Untuk kepentingan Negara aturan perkawinan sebagai landasan utama mengatur warga negaranya agar tercipta ketertiban dan ketentraman. Meskipun aturanya bersifat dinamis dari waktu ke waktu. ${ }^{2}$ Sedangkan kepentingan perempuan yang memiliki harapan dapat memperbaiki dan meningkatkan derajat perempuan.

Dalam konteks efektivitas peraturan perkawinan untuk meminimalisir problematika perkawinan terdapat beberapa penelitian sebelumnya yang relevan di antaranya yaitu : Samsidar dan kawan kawan dalam penelitiannya tentang efektivitas pencatatan perkawinan di Kabupaten Polewali Mandar menyatakan bahwa pencatatan perkawinan sudah merupakan aspek marginal. Selain itu kesadaran dan pandangan hukum di masyarakat sudah relatif tinggi. Masyarakat sudah menyadari bahwa perkawinan tanpa dicatatkan termasuk perkawinan yang illegal atau di bawah tangan sedangkan perkawinan yang dicatatkan adalah perkawinan yang resmi dan diakui oleh pemerintah sehingga berkuatan hukum. ${ }^{3}$

Selain itu ada juga penelitian dari Musyarrofa Rahmawati dan kawan kawan tentang efektivitas pembatasan usia perkawinan di wilayah Ponorogo. Dalam kesimpulannya

\footnotetext{
${ }^{1}$ Sajtipto Raharjo, Hukum dan Perubahan Sosial (Bandung: Alumni, 1979), hlm. 146-147.

${ }^{2}$ Irfan Supandi, Keajaiban Berumah Tangga (Solo: Tinta Medina, 2012), hlm. 1-2.

${ }^{3}$ Samsidar dan Syamsudin dan Sri Lestari Poernomo, "Efektivitas Pencatatan Perkainan Menurut Undang-undang Nomor 1 Tahun 1974 (Studi di Kapuaten Polewali Mandar)", Holrev Faculty of law, Halu Oleo University Kendari, Vol. 3 ; (2019) : $116: 131$.
} 
TAHKIM, Jurnal Peradaban dan Hukum Islam. Vol.4 No.l (Maret, 202I) | ISSN : 2597-7962

bahwa pembatasan usia perkawinan di Ponorogo belumlah efektif karena masih banyak angka perkawianan usia muda. Hal ini disebabkan adanya perjodohan anak, hamil di luar nikah, hingga budaya di masyarakat tentang nikah muda. ${ }^{4}$

Berbeda dengan Musyarrofa Rahmawati dan kawan kawan, Ni luh ginastini dan $\mathrm{Hj}$. Rina Suwasti menjelaskan bahwa efektifitas pasal 7 ayat 2 Undang-undang perkawinan sudah efektif. Hal ini dilihat dari hasil penelitiannya di Desa Mekarsari, Kecamatan Gunungsari Lombok Barat dari 4652 jiwa hanya 362 jiwa yang melakukan nikah di bawah umur atau sekitar $8 \%$. Keefektifitasan ini tak terlepas dari peran tokoh masyarakat dalam memberikan sosialisasi, penyuluhan serta pendekatan kepada masyarakat akan dampak dari pernikahan di bawah umur. ${ }^{5}$

Berbeda dengan penelitian diatas yang hanya membahas dari segi satu problematika dan suatu daerah. Dalam penelitian ini penulis membahas secara komprehensif efektivitas peraturan perkawinan dalam meminimalisir problematika perkawinan.

\section{B. METODE PENELITIAN}

Jenis penelitian ini adalah kualitatif melaui studi kepustakaan dengan pendekatan yuridis normatif. Adapun sumber data penelitian ini yaitu data sekunder atau data kepustakaan dan dokumen hukum yang berupa bahan-bahan hukum. Penelitian ini menggunakan studi pustaka maka data-datanya diperoleh dari pustaka seperti undangundang, peraturan pemerintah, kompilasi hukum Islam, buku, jurnal penelitian, majalah, surat kabar dan catatan lainnya yang relevan dengan penelitian. Sedangkan metode analisis penelitian ini termasuk dalam deskriptif analisis yang mendiskripsikan dan menganalisa masalah yang ada dalam jenis penelitian kepustakaan (library researdh) yang disajikan secara deskriptif. ${ }^{6}$

\section{PEMBAHASAN}

Apabila membicarakan efektifitas ${ }^{7}$ hukum dalam masyarakat Indonesia berarti membicarakan daya kerja hukum dalam mengatur dan/atau memaksa warga

\footnotetext{
${ }^{4}$ Musyarrofa Rahmawati dan Hanif Nur Widhiyanti dan Warkum Sumitro," Efektifitas Pembatasan Usia Perkawinan Berdasarkan Undang-undang Nomor 1 Tahun 1974 tentang Perkawinan," Jurnal Ilmiah Pendidikan Pancasila dan Kewarganegaraan, Vol. 3 ; (2018) :100-105.

${ }^{5} \mathrm{Ni}$ Luh Ginastini dan Hj. Rina Suwasti," Efektifitas Undang undang Nomor 1 Tahun 1974 terhadap Perkainan Anak di Bawah Umur (Studi Kasus di Desa Mekarsari Kecamatan Gunungsari Kabupaten Lombok Barat)", Jurnal Gara UNMAS Denpasar, Vol.13 ; (2019) ; 326-331.

${ }^{6}$ Gumilar Rusliwa Somantri, "Memahami Metode Kualitatif," Makara Hubs Asia, Vol. 9, Desember 2005

${ }^{7}$ Efektifitas berasal dari kata dasar efektif. Menurut Kamus Besar Bahasa Indonesia, kata efektif mempunyai arti efek, pengaruh, akibat atau dapat membawa hasil. Jadi, efektifitas adalah keaktifan, daya
} 
TAHKIM, Jurnal Peradaban dan Hukum Islam. Vol.4 No.l (Maret, 202l) | ISSN : 2597-7962

masyarakat untuk taat terhadap hukum. ${ }^{8}$ Efektifitas hukum yang dimaksud, berarti mengkaji kaidah hukum yang harus memenuhi syarat, yaitu: berlaku secara filosofis, berlaku secara yuridis, dan berlaku secara sosiologis. ${ }^{9}$ Bagi studi hukum dalam masyarakat, maka yang terpenting adalah hal berlakunya hukum secara sosiologis ( efektifitas hukum). ${ }^{10}$

Efektifitas pada dasarnya menunjukkan pada taraf tercapainya hasil, sering atau senantiasa dikaitkan dengan pengertian efisien, meskipun sebenarnya ada perbedaan di antara keduanya. Efektifitas menekankan pada hasil yang dicapai, sedangkan efisiensi lebih melihat pada bagaimana cara mencapai hasil yang dicapai itu dengan membandingkan antara input dan outputnya.

Efektifitas hukum adalah menelaah apakah hukum itu berlaku, dalam hal ini meminimalisir perceraian, dan untuk mengetahui berlakunya hukum tersebut, sebagaimana dikutip Muslan Abdurrahman, Donald Black menganjurkan agar membandingkan antara ideal hukum, yakni kaidah yang dirumuskan dalam undangundang dengan realitas hukum ${ }^{11}$. Soerjono Soekanto ${ }^{12}$, berkaitan dengan realitas hukum ini, menyatakan apabila seseorang mengatakan bahwa suatu kaidah hukum berhasil atau gagal mencapai tujuannya, maka hal itu biasanya diukur apakah pengaruhnya berhasil mengatur sikap tindakan atau perilaku tertentu, sehingga sesuai dengan tujuannya atau tidak.

guna, adanya kesesuaian dalam suatu kegiatan orang yang melaksanakan tugas dengan sasaran yang dituju.Poerwadarminta,W.J.S. Kamus Umum Bahasa Indonesia, Edisi III, Cet. Ke-3, (Jakarta : Pusat Bahasa Departemen Pendidikan Nasional, 2006), hlm. 311.

Secara terminologi, menurut Hans Kelsen, 1967 Sebagaimana dikutip Purnadi Purbacaraka dan Soerjono Soekanto, effectiveness is a condition of validity in the sense that effectiveness has to join the positing of a legal norm if the norm is not to lose its validity. Purnadi Purbacaraka dan Soerjono Soekanto, Perihal kaidah hukum, (Bandung : Citra Aditiya Bhakti, 1978), hlm. 23.

${ }^{8}$ Zainuddin Ali, Filsafat Hukum, (Jakarta : Sinar Grafika, 2011), hlm. 94.

${ }^{9}$ Menurut Hans Kelsen berlaku secara filosofis artinya kaidah hukum berlaku apabila dipandang sesuai dengan cita- cita masyarakat, Kaidah hukum berlaku secara yuridis, apabila penentuanya didasarkan pada kaidah yang lebih tinggi atau berbentuk menurut cara yang telah ditetapkan atau apabila menunjukan hubungan keharusan antara kondisi dan akibat, kaidah hukum berlaku secara sosiologis apabila kaidah tersebut efektif, artinya kaidah tersebut dapat dipaksakan berlakunya oleh penguasa walaupun tidak diterima oleh warga masyarakat (teori kekuasaan), atau kaidah tersebut berlaku karena diterima dan diakui oleh masyarakat (teori pengakuan). Sudikno Mertokusumo, Mengenal Hukum (Suatu Pengantar), (Yogyakarta : Liberty Yogyakarta, 1999), hlm. 87 - 89. Lihat juga Purnadi Purbacaraka dan Soerjono Soekanto, Perihal kaidah hukum, hlm. 114-117.

${ }^{10}$ Muslan Abdurrahman, Sosiologi dan Metode Penelitian Hukum, (Malang, UMM Press), hlm. 30.

${ }^{11}$ Muslan Abdurrahman, Sosiologi dan Metode Penelitian Hukum, hlm. 34. hlm. 7 .

12 Soerjono Soekanto, Kesadaran Hukum \& Kepatuhan Hukum, (Jakarta : Rajawali Press, 1983), 
TAHKIM, Jurnal Peradaban dan Hukum Islam. Vol.4 No.l (Maret, 202I) | ISSN : 2597-7962

Untuk melihat sejauh mana efektivitas Undang-Undang perkawinan di Indonesia kita bisa melihat dari dua periode. Pertama, efektivitas dilihat dari sebelum dibuat Undang-undang sampai sesudah dibuat Undang-undang, kedua efektivitas dilihat sejak lahirnya peraturan perkawinan sampai dengan sekarang.

\section{Efektivitas Undang - undang Perkawinan dalam Meminimalisir Problematika}

\section{Pra Perundang-undangan}

Berdasarkan hasil sejumlah penelitian sebelum lahirnya pertauran perkawinan.beberapa penelitian menyimpulkan, dengan adanya Undang-undang perkawinan ternyata dapat rnenurunkan tingkat perceraian. Menurut Katz, peraturan perkawinan di Indonesia dapat menurunkan tingkat perceraian sangat signifikan, yaitu sekitar $70 \%$ setelah berlaku selama lima tahun. ${ }^{13}$

Selain itu ada juga penelitian dari Gavin W. Jones dan kawan-kawan, dengan mengambil penelitian di Jawa Barat. Dalam kesimpulannya salah satu faktor penyebab penurunan tingkat perceraian secara dratis di Indramayu disebabkan karena diberlakunya peraturan tentang perkawinan di Indonesia. Lebih lanjut penurunan tersebut di pengaruhi oleh beberapa faktor yaitu : (1) adanya peningkatan batas usia perkawinan; dan (2) menurnnya tingkat perjodohan atau kawian paksa sehingga anak bebas menentukan calon pasangannya. ${ }^{14}$ Senada dengan Gavin, Simon Butt dalam penelitiannya juga menyimpulkan penurunan praktek poligami di Indonesia sejak di berlakukannya aturan tentang perkawinan namun demikian Simon Butt tidak menyebutkan angka secara spesifik tingkat penurunannya. ${ }^{15}$

Hal demikian juga di kemukakan dalam penelitian Mack Cammack dan kawankawan meskipun bukan satu satunya faktor yang mempengaruhi tingkat penurunan namun keberadaan peraturan perkawian cukuplah berpengaruh dalam tingkat penurunan perceraian di Indonesia. ${ }^{16}$

${ }^{13}$ Lihat June S. Katz \& Ronald S. Katz, "Legislating Social Change in a Developing Country: The New Indonesian Marriage Law Revised", dalam The American Journal of Comparative Law, Vol.26, (1978), hlm. 310.

14 Gavin Jones, Yahya Asan dan Tuti Djuartika, "Divorce in West Java", dalam Journal of Comparative Family Studies, Vol. 25, No. 3 (Musim Gugur, 1994), hIm. 414.

${ }^{15}$ Simon Butt, "Polygamy and Mixed Marriage in Indonesia: The Application ofthe Marriage Law in the Courts,' dalam INDONESIA: Law and Society, diedit oleh Timothy Lindsey (NSW : The Federation Press, 1999), hlm. 131-132.

${ }^{16}$ Mark Cammack, Lawrence A. Young dan Tim B. Keaton, “An Empirical Assessment of Divorce Law in Indonesia,” dalam Studia Islamika, Vol. 4, No. 4 (1997), hIm. 102. 
TAHKIM, Jurnal Peradaban dan Hukum Islam. Vol.4 No.l (Maret, 202I) | ISSN : 2597-7962

Kesimpulan penelitian Cammack didasarkan pada sejumlah alasan yaitu kesimpulan dari penelitian Garvin Jones ${ }^{17}$ yang mencatat jumlah perceraian di Pengadilan Agama, penurunan angka perceraian sebanyak $70 \%$ sejak diberlakukannya peratura perkawinan, hasil penelitian Ashari dan Djuritkan di daerah Jawa Barat pada tahun 1976 yang menyimpulkan setelah di berlakukannya aturan perkawinan tingkat perceraian jadi turun, dan sudah menjadi asumsi umum bahwa adanya peraturan perkainan dapat meminimalisir tingkat perceraian. ${ }^{18}$

Kemudian tentang efektivitas peraturan perkainan dalam meminimalisir perceraian sepihak dari suami dan kawin paksa hasil penelitian dari Sita Van Bemmelen di daerah Minahasa antara tahun 1861 sampai dengan 1933 menyimpulkan adanya peraturan tersebut dapat meminimalisir perceraian sepihak dan kawin paksa meskipun penelitian ini bukan di kalangan orang muslim. ${ }^{19}$

Respons positif lain juga dihasilkan dari penelitian Moh. Zahid. ${ }^{20}$, dalam beberapa hal Undang-undang Perkawinan di Indonesia sudah sesuai tujuannya di anataranya meningkatkan batas usia perkawinan dan mengurangi perkawinan usia dini, memperketat adanya poligami suami, menurunkan tingkat perceraian, dan mengusahakan kesetaraan antara suami dan istri.

Namun demikian ada satu kelemahan pada hasil penelitian di atas yaitu apada sumber data yang digunakan berasal dari data resmi Badan Pusat Data Statistik dan Pengadilan Agama. Padahal banyak kasus yang tidak tercatatkan di dua lembaga tersebut terjadi dim masyarakat. Kelemahan penelitian tersebut juga di dukung dengan penelitian dari Julia I. Suryakusuma yang meneliti tentang Peraturan Pemerintah Nomor 10 Tahun 1983. Hasil kesimpulannya menunjukan di pengadilan angka poligami memang menurun dikalangan PNS tetapi di lapangan juga semakin bertambah perkawinan sirii, perselingkuhan dan isteri simpanan. ${ }^{21}$ Meskipun terdapat kelemahan dari peraturan

\footnotetext{
${ }^{17}$ Gavin W. Jones, Marriage and Divorce in Islamic Sourh-\&isi Asia (Oxford, Singapore and New York : Oxford University Press, 1994).

${ }^{18}$ Mark Cammack dkk., "An Empirical Assessment of Divorce Law in indonesia,” hlm. 102.

${ }^{19}$ Sita van Bemmelen, "The Marriage of Minahasa Women in the Periode 1861-1933," dalam Indonesian Women in Focus : Past and Present Notions, diedit oleh Elsbeth Locher-Scholten and Anke Niehof (Dordrecht: Foris Publications, I 987), hlm. I 81-204.

20 Moh. Zahid, "Dua Dasawarsa Undang-undang Perkawinan", DIALOG. fumai Studi dan informasi keagamaan, Badan Penelitian dan Pengembangan Agama Depag., No. 39, Th. XVIII, Maret 1994, hIm. 33-40. Adapun kelemahan yang dimaksud dalam tulisari ini adalah: (1) tidak adanya aturan tentang perkawman campuran, dan (2) kurang jelasnya hukuman bagi pelanggar. hlm.264.

${ }^{21}$ Khoiruddin Nasution, Pengantar Studi Islam (Jakarta : Raja Grafindo Persada, 2016), hlm. 265.
} 
TAHKIM, Jurnal Peradaban dan Hukum Islam. Vol.4 No.l (Maret, 202I) | ISSN : 2597-7962

poligami di kalangan PNS akan tetapi sejumlah responden menyatakan bahwa adanya peraturan ini masih di butuhkan setidaknya untuk meminimalisir poligami di kalagan PNS secara dan perceraian yang tidak sewenang wenang.

Masyarakat tidak memilih Pengadilan Agama bisa ditinjau dari hasil penelitian melaui Data Pusat Statistik di Kabupaten Gunung Kidul Yogyakarta dan data resmi Pengadilan Agama bahwa masyarakat di Desa tidak menyelesaikan perceraian, poligami maupun permasalahan perkawianan lainnya ke Pengadilan Agama. Bagi masyarakat di Desa Pengadilan merupakan lembaga yang seram sebisa mungkin di jauhi.

Hal tersebut juga di dukung dengan hasil penelitian dari Hildred Greetz di Modjokerto Daerah Jawa Timur bahwa masyarakat menanggap bahwa lembaga Pengadilan Agama sebisa mungkin dijauhi hanya saja perbedaan penelitian di Gunung Kidul yang menanggap Penggadilan Agama yang identik dengan masalah maka peneltian Hildred di Modjokerto Pengadilan Agama di anggap sebuah lembaga yang seram untuk di takuti.

Sebaliknya, Nakamura mempunyai kesimpulan yang berbeda dengan kedua penelitian tersebut. Bagi masyarakat Yogyakarta (Kodya), tempat penelitian Nakamura, lembaga Peradilan Agama adalah suatu lembaga biasa yang mengakar dan umum digunakan oleh masyarakat untuk menyelesaikan masalah-masalah perkawinan. ${ }^{22}$ Dari beberapa hasil penelitian tersebut di atas dapat disimpulkan factor wilayah kota atau desa, dan tingkat pendidikan pihak yang berpekara, cukup menentukan terhadap kesan tersebut. Untuk masyarakat desa dan bagi mereka yang kurang pendidikan, lembaga Peradilan mungkin memang dianggap sebagai lembaga yang ditakuti, sementara untuk masyarakat kota dan yang cukup berpendidikan, kesan seperti itu tidak ada.

\section{Efektivitas Undang-undang Perkawinan dalam Meminimalisir Problematika}

\section{Pasca Perundang-undangan}

Selanjutnya untuk mengetahui efektivitas peraturan perkawinan sejak dibuat sampai dengan masa sekarang dapat ditinjau dari beberapa indikator di antaranya yaitu .23

a. Hukumnya sendiri

${ }^{22}$ Hisako Nakamura, Perceraian Orang Jawa, terj.H.Zaini Ahmad Noeh (Yogyakarta : Gajah Mada University Press, 1991), hlm.79.

${ }^{23}$ Soerjono Soekanto, Faktor - faktor yang Mempengaruhi Penegakan Hukum, Cet. Ke-11 (Jakarta : Raja Grafindo Persada, 2012), hlm.8-9. 
TAHKIM, Jurnal Peradaban dan Hukum Islam. Vol.4 No.l (Maret, 202I) | ISSN : 2597-7962
b. Penegak hukum
c. Sarana dan fasilitas
d. Masyarakat
e. Budaya hukum

Faktor Pertama, mengenai hukumnya, peraturan perkawinan terdapat pasal yang dinilai masih kapabel dan bias gender. ${ }^{24}$ Meskipun peraturan perkawinan sudah mengalami revisi namun problematika perkawinan masih banyak ditemukan dalam peraturan terbaru. Hal itu karena pemerintah hanya merubah sebagian pasal perawturan perkawinan yaitu batas usia perkawinan. Selain itu ketimpangan relasi atau bias gender dalam melihat hukum dan hak-hak perempuan juga justru menjadikan perempuan tidak cukup kapabel untuk mendapat hak-haknya terutama isu-isu krusial poligami, perceraian, nafkah bagi isteri, syarat sah kawin, status anak luar kawin dan status kepala keluarga. Menurut Divisi Reformasi Hukum dan Kebijakan Komnas Perempuan, ada beberapa ketentuan aturan perkawinan yang perlu ditinjau kembali, karena sudah tidak relevan dengan kebutuhan masyarakat dewasa ini. Diantara pasal-pasal tersebut adalah :

a. Perbedaan adanya masa iddah hanya bagi isteri setelah terjadinya perceraian di banding laki-laki yang bebas beraktivitas kerja di luar rumah (Pasal 11)

b. Masih adanya pasal yang menyebutkan perkawinan capuran dapat memperoleh atau kehilangan kewarganegaraan dari suami/isteri (Pasal 58)

c. Masih adanya beberapa kasus yang memaknai aturan yang mengharuskan nikah di luar negeri jika terjadi perkawianan beda agama untuk mendapatkan legalitas dari Negara melalui catatan sipil (Pasal 2 ayat 1$){ }^{25}$

Hal ini diperparah dengan beberapa prinsip hukum islam dimana alih-alih membela hak perempuan justru tidak cukup kuat memposisikan perempuan sejajar dengan lakilaki. KHI sebagai pegangan hakim agama memutuskan perkara di pengadilan dianggap masih menerapkan stereotype karena budaya patriakal di masyarakat ${ }^{26}$ sehingga tidak menutup kemungkinan putusan hakim yang diambil dari sinipun patriarkis. Menurut penelitian Euis Nurlelawati, KHI adalah hasil dari pergumulan politik hukum antara

\footnotetext{
${ }^{24}$ Abdullah Ahmed An-Naim, Dekonstruksi Syariah. Penerjemah Ahmed Suedy dan Aminuddin ar-Rani (Yogyakarta, Elkis, 2004),hlm.291.

${ }^{25}$ Yulianti Muthmaimah,’Penting,Revisi Undang-Undang Perkawinan”, Komnas Perempuan, 29 Juni 2009

${ }^{26}$. Euis Nurlelawati, Modernization Tradition and Identily : The Kompilasi Hukum Islam and legal Practice in the Indonesian Religion Court, hlm.103.
} 
TAHKIM, Jurnal Peradaban dan Hukum Islam. Vol.4 No.l (Maret, 202l) | ISSN : 2597-7962

hukum Isalm, kebijakan Negara, dan hukum adat. Demikian pula dalam berbagai kitab kuning seorang perempuan diibaratkan sebagai mahluk yang melebur dengan laki-laki, setengah jika di bandingkan harga laki-laki, sebagai objek dan makhluk domestik. ${ }^{27}$ Meskipun ada juga beberapa kitab kuning klasik yang menganggap kedudukan perempuan lebih tinggi dibandingkan laki-laki atau setidaknya setara.

Faktor Kedua, penegak hukum atau hakim dalam mempengaruhi efektivitas peraturan perkawinan tidak berpengaruh banyak dalam meminimalisir problematika perkawinan. Hal tersebut disebabkan oleh rendahnya sensitivitas gender di kalangan penegak hukum. Peradilan Agama sebagai lembaga yang di percaya umat Islam untuk penyelesaian problematika perkawinan lebih dominan dipengaruhi oleh kultur Peradilan Agama itu sendiri dibandingkan dengan struktur hukum dan substansi hukum. Hal tersebut dikarena masih adanya budaya dan kebiasaan mengambil dalil kitab kuning klasik di bandingkan KHI yang sudah di kodifikasikan.

Menurut hasil penelitian Noryamin Aini tentang sumber rujukan yang diambil hakim dalam memutus perkara. Dalam kesimpulannya 35,5\% hakim agama mengutip KHI sebagai rujukan utama dalam memutuskan perkara. ${ }^{28}$ Sedangkan selebihnya $65,2 \%$ tidsk mengutip. Angka yang tidak jauh berbeda terlihat dalam pengutipan kitab kuning oleh hakim, yaitu hanya $32,7 \%$ yang mengutip dan $67,3 \%$ yang tidak mengutip kitabkitab kuning. ${ }^{29}$ Selain temuan diatas, menurut penelitian ini disebutkan pula bahwa anatar KHI dan kitab kuning memiliki kedekatan kultur yang sulit dipisahkan, karena dari putusan hakim yang mengutip KHI (47,2\%) secara silmutan juga mengutip kitab kuning $(44,7 \%)$, tapi tidak sebaliknya. Masih kuatnya tradisi kitab kuning dalam pengadilan ini, sebagai kesimpulan penelitian ini, maka dimensi yuridis formal hukum tidak serta merta menjadikannya aturan yang langsung berlaku dan ditaati. ${ }^{30} \mathrm{Hal}$ inilah yang dinyatakan

\footnotetext{
${ }^{27}$ Masdar F. Mas'udi, Perempuan di Antara Lembaran Kitab Kuning, dalam Lieas marcoes Natsir dan Johan Hendrik Meuleman, Wanita Islam Indonesia dalam Kajian Tekstual dan Kontekstual (Jakarta, INIS, 1993),hlm.155.

${ }^{28}$ Penelitian ini menganalisis 110 buah dokumen putusan yang ada di Pengadilan Agama Jakarta Selatan mulai tahun 1995 sampai tahun 1998. Dengan jumlah putusan tersebut, penelitian ini melibatkan 20 orang hakim, dari seluruh jumlah persidangan, sehingga satu orang hakim melakukan persidangan sebanyak 2 samapi 3 kali dalam periode penelitian.

${ }^{29}$ Nuryamin Aini, Budaya Hukum : Melintas Batas Formalitas-Yuridis Sentralitas Kompilasi Hukum Islam dan Kitab Kuning dalm putusan Pengadilan Agama, hlm 5. Hasil penelitian dimuat dalam jurnal Ilmiah Ilmu Hukum, Era Hukum, No.3 Tahun 9 Mei Tahun 2002: Meskipun dalam penelitian ini disebutkan bahwa dari tahun ke tahun (dalam bahasa penelitian ) terjadi peningkatan pengutipan KHI, mulai dari hanya $19,0 \%$ pada $1995,20,0 \%$ pada $1996,37,0 \%$ pada 1997 dan terakhir 56,5\% pada 1998.

${ }^{30}$ Nuryamin Aini, Budaya Hukum : Melintas Batas Formalitas-Yuridis.,hlm17. Menurut Euis Nurlelawati, para hakim pun mengunakan ijtihad dalam penetapan putusan dipengadilan. Hal ini
} 
TAHKIM, Jurnal Peradaban dan Hukum Islam. Vol.4 No.l (Maret, 202I) | ISSN : 2597-7962

oleh beberapa ahli antropologi hukum bahwa pada prinsipnya suatu hukum akan berada pada suatu area negosiasi, saling mempengaruhi, dan membentuk norma-norma baru. ${ }^{31}$ Melihat fakta diatas, cukup sulit bagaimana sensitivitas gender hakim dalam memutus perkara, karena di tengah arus perkembangan posivitisme hukum tersebut, hakim agama masih memegang tradisi yang melingkupinya, sehingga putusanya pun tidak dapat dilihat secara monolitik dan bersumber dari hukum yang berbeda-beda. ${ }^{32}$

Sebagai contoh pada tahun 1952, Pengadilan Jombang pernah memutus perkara tentang poligami. Namun berbeda dengan beberapa kasus pada pengadilan agama saat ini, dalam perkara tersebut yang menjadi persoalan adalah status perkawinan kelima seorang lelaki yang ditinggal oleh salah satu isterinya. Pengadilan Agama jombang menganggap perkawinan ini fasid.Yang menarik disini, putusan Pengadilan Agama tersebut dibatalkan oleh Makamah Islam Tinggi dengan mengutip beberapa kitab fikih. ${ }^{33}$ Hemat penulis bahwa Indikator lemahnya sensitivitas hakim dapat dilihat dari tingginya izin poligami yang di berikan oleh hakim-hakim Pengadilan Agama. Data Departemen Agama Menunjukan, hampir $80 \%$ pengajuan poligami dikabulkan. ${ }^{34}$

Selain itu dalam kasus KDRT yang diputusankan oleh Pengadilan Agama dapat dikelompokkan menjadi empat kasus, yakni : kekerasan akibat ekonomi, tidak adanya tanggung jawab suami, cerai talak, dan cerai gugat. Semua kasus yang menyangkut kekerasan akibat ekonomi dan tidak adanya tanggung jawab suami dapat diproses dan diputuskan dengan selesai. Dalam Laporan Tahunan Komnas Perempuan, sepanjang 2004, tercatat adanya perceraian sebanyak 560 kasus di Pengadilan Agama Jakarta Utara dan hampir setegahnya 250 kasus adalah perceraian dikarenakan kekerasan terhadap

(pengunaan beberapa sumber diluar KHI ini) dilator belakangi beberapa faktor, diantaranya kekurangmampuan KHI menghadapi problematika dan perkara yang masuk ke pengadilan. Euis Nurlelawati, Modernization Tradition and Moderntily., hlm.211.

31 Sally Folk Moore, Hukum dan Perubahan sosial, dalam T.O.Ihromi,Antropologi Hukum, hlm.152. E.K.M. Masinambo, Antropologi dan Study Hukum, dalam Masinambow,(ed), Hukum dan Kemajemukan Budaya, (Jakarta, YOI,2003),hlm.1-2.

32 Dalam penelitian ini Noryamin membandingkan dua wilayah yang berbeda, di antaranya Sumatra Utara, Jawa Barat, Kalimantan Selatan dan Bali, yang kesemua putusanya dimana didominasi KHI. Sementara antara Jakarta Selatan dan Banjarmasin sangat berbeda, dimana para hakim dijakarta sangat jarang mengutip kitab kuning dibandingkan dengan Banjarmasin yang sering mengutip kitab kuning, meskipun suatu perkara ditetapkan jelas dalam Undang-Undang Perkawinan.

${ }^{33}$ Beberapa putusan pengadilan agama Islam (yang menjadi yurisprudensi) sebelum terbentuk Undang-Undang Perkawinan. Hasbullah Bakry, Kumpulan Lengkap Undang-Undang Perkawinan di Indonesia (Jakarta : Djambatan, 1981),hlm.183.

${ }^{34}$ Nasarudin Umar,"Refleksi Penerapan Hukum Keluarga di Indonesia,"hlm.2. makalah diakses dari Komnas Perempuan.wwwkomnasperempuan.com 
TAHKIM, Jurnal Peradaban dan Hukum Islam. Vol.4 No.l (Maret, 202l) | ISSN : 2597-7962

perempuan (KTP), sedangkan di Pengadilan Agama Manado tercatat 117 kasus perceraian karena alasan KDRT.

Kemudian pada tahun 2006 kasus KDRT adalah kasus yang paling banyak ditangani oleh Pengadilan Agama akibat penelantaran ekonomi. Pengadilan Agama lebih banyak menagani kasus KDRT di banding lembaga mitra Komnas Perempuan lainya, karena Pengadilan Agama menjadi lembaga yang sering didatangi korban secara langsung (3.510 kasus, 59\%). Adapun kasus yang ditangani kekerasan akibat ekonomi (20\%) dan dalam kasus perceraian mencapai $85 \%$ dari seluruh kasus kekersan akibat ekonomi. ${ }^{35}$ Persepsi para hakim dilapangan diakui masih harus dilakukan peningkatan kapsitas mereka untuk bisa memutuskan perkara yang berkeadilan gender. Menyikapi hal ini, terkaitpula sensitivitas hakim Agama ini, Komnas Perempuan membuat buku pedoman bagi hakim Agama di seluruh Indonesia, terutama terkait dengan penyelesaian kasus-kasus KDRT yang lebih memperhatikan kepentingan perempuan. ${ }^{36}$

Faktor ketiga, fasilitas yang mendukung. Untuk mencapai keadilan masyarakat sudah seharusnya tersedia fasilitas yang menunjang bekerjanya hukum sebagai sarana untuk mencapai tujuan hukum. Standar fasilitas pendukung seharusnya berupa : ruang tunggu yang nyaman, kaukus papan nama daftar mediator, ATK meja bundar atau oval, ruang mediasi yang kondusif, papan alur administrasi mediasi, kursi, register mediator (hakim/non hakim), komputer serta proyektor. Akan tetapi fasilitas penunjang tersebut dalam realitasnya di Pengadilan Agama belum memadai terutama di daerah daerah. Misalnya tersedianya komputer, proyektor dan layar di ruang mediasi belum ada. Meja di ruang mediasi masih menggunakan meja kayu biasa bukan meja oval atau bundar, tidak dipisakan anatar ruang tunggu masyarakat dengan ruang tunggu pihak yang berperkara. ${ }^{37}$

Faktor keempat dan kelima, terkait dengan masyarakat dan budaya hukum, pengertian masyarakat memiliki banyak arti dan ruang lingkup yang luas. Dalam artian umum masyarakat merupakan sekelompok manusia yang mempunyai sistem tertentu, tradisi tertentu dan mengarah pada kehidupan kolektif. Hal ini karna manusia dari segi pergaulan hidup terikat akan nilai-nilai dan norma-norma yang hidup di masyarakat. Oleh

${ }^{35}$ Komnas Perempuan, catatan Tahunan Kekerasan terhadap perempuan tahun 2006, hlm.3-11.

${ }^{36}$ Faqihuddin Abdul Kodir dan Ummu Azizah Munaqrkawati, Referensi bagi Hakim Peradilan Agama tentang kekerasan dalam Rumah Tangga (Jakarta : Komnas Perempuan), diakses dari www.komnas perempuan.or.id

${ }^{37}$ Triana Sofiani, Efektifitas Mediasi Perkara Perceraian Pasca Perma Nomor 1 Tahun 2008 di Pengadilan Agama, Jurnal Penelitian IAIN Pekalongan, Vol 7 N0 2, tahun 2010, hlm5 
TAHKIM, Jurnal Peradaban dan Hukum Islam. Vol.4 No.l (Maret, 202I) | ISSN : 2597-7962

karena itu, budaya hukum yang merupakan ide, harapan dan sikap manusia terhadap hokum dalah penentu hokum akan di salah gunakan atau tidak. Budaya hukum inilah yang akan membentuk masyarakat akan kesadaran hukum. Dimana masyarakat berperilaku sebagaimana kehendak hukum. Kesadaran hukum adalah penghubung antara perilaku hukum masyarakat dengan substansi hukum (aturan).

Namun demikian harus diakui bahwa masyarakat lebih mengenal dan lebih dekat dengan hukum Islam dibandingkan dengan peraturan Undang-Undang Perkawinan di Indonesia. Meskipun hukum adat pun cukup kuat dikenal oleh masyarakat atau beberapa wilayah lebih kuat dengan hukum adat. Merujuk pada penelitian Ahmad Tholabi Kharlie, diwilayah lebak Banten yang menyertakan 395 responden yang diambil secara acak (random sampling), dapat di ketahui bahwa mayoritas masyarakat $(76,7 \%)$ lebih mengetahui hokum Islam dibandingkan dengan hukum adat $(14,2 \%)$ ataupun hukum Barat $(9,2 \%) .{ }^{38}$

Kedekatan masyarakat terhadapa hukum Islam sangat mungkin terjadi, apalagi hukum Islam sudah mengakar di masyarakat sejak lama. Selain itu hasil penelitian dari The Asia Foundation terhadap enam propinsi di Indonesia, dengan klasifikasi urban, rural, dan seni urban, dapat disebutkan bahwa keterikatan dan ketergantungan masyarakat Indonesia terhadap tokoh agama masih sangat kuat. Hal ini di tandai dari kepercayaan terhadap tokoh-tokoh tersebut yang mencapai 94\%. Angka ini sedikit lebih rendah dengan kepercayaan masyarakat terhadap kelembagaan kepolisian dan aparat setempat yang mencapai $99-1000 \% .{ }^{39}$

Bila dikaitkan dengan penelitian lain sangat, bisa ditarik kesimpulan bahwa fenomena masyarakat lebih suka menyelesakan masalahnya secara kekeluargaan daripada hukum formal yaitu 70\% dibandingkan dengan Pengadilan Agama 30\%. Hal ini menunjukan bahwa masyarakat merasa aman dan adil jika permasalahan perkawinan

\footnotetext{
${ }^{38}$ Ahmad Tholabi Kharlie, Kesadaran Hukum Masyarakat terhadap Terhadap Hukum Perkawinan (Jakarta : Lemit UIN Jakarta dan UIN Press, 2009),hlm.121.

39 The Asia Foundation, Citizent'Perception of the Indonesian Justice Sector : Survey Report (Jakarta : The Asia Foundation,2005),hlm.42.
} 
TAHKIM, Jurnal Peradaban dan Hukum Islam. Vol.4 No.l (Maret, 202l) | ISSN : 2597-7962

seperti perceraian, poligami, $\mathrm{KDRT}^{40}$, perkawinan di bawah umur $^{41}$ lebih nyaman dan adil bila diselesaikan secara kekeluargaan. ${ }^{42}$

Selain data diatas, pilihan dan kesadaran hukum masyarakat, terutama bagi perempuan dapat dilihat dari data statistik perkara yang ada di Pengadilan Agama setiap tahunnya. Rata-rata di setiap Pengadilan Agama di Indonesia setiap perkara cerai gugat mendominasi dibandingkan cerai talak. Dari 2001 hingga 2005, perkara yang di terima Pengadilan Agama sebanyak 4777.464 perkara, sedangkan cerai talak hanya 314.524 perkara dan perkara lainnya sebanyak 40.758 perkara. ${ }^{43}$

Dari berbagai problematika di atas menurut penulis, peraturan perkawinan yang telah ada sekarang sudah tidak relevan dengan kondisi sekarang. Oleh karna itu melakukan pembaharuan adalah sebuah keniscayaan dalam konteks kekinian dan kesinian sesuai dengan kondisi Negara Indonesia.

Dari data-data di atas hemat penulis peraturan perakwinan yang ada sekarang sudah tidak relevan dengan kondisi sekarang. Terakhir revisi undang undang hanya sebatas perpasal yaitu batas usia nikah. Sedangkan masih banyak peraturan perkawinan yang di

\footnotetext{
${ }^{40}$ Sepanjang tahun 2016 komnas Perempuan Indonesia mencatat terdapat 259.150 kasus KDRT yang dihimpun dari lembaga mitra pengadaan layan dan Pengadilan Agama di Indonsia. Dari seluruh data yang dihimpun Pengadilan Agama $94 \%$ kasus kekerasan berujung pada perceraian atau sekitar 245.548 kasus. Sedangkan data yang dihimpun lembaga mitra pengaduan layanan mencatat 10.205 kasus kekerasan terhadap perempuan terjadi di ranah personal.

Selain data dari dua lembaga tadi pengaduan terhadap kasus KDRT yang langsung diadukan ke Komnas Perempuan juga masih tinggi yaitu 903 kasus dari jumlah seluruh 1.022 pengaduan. Komnas Perempuan membagau kekerasan terhadap perempuan menjadi tiga bagian yaitu kekerasan di ranah Negara, komunitas dan personal. Kekerasan paling banyak terjadi di ranah personal/rumah tangga ada 5.784 kasus, kekerasan dalam masa pacaran ada 2.171 kasus dan kekerasan terhadap anak perempuan 1.799 kasus sisanya kekerasan yang dilakukan mantan suami atau pacar terhadap pekerja rumah tangga. http://www.bbc.com/indonesia/indonesia-39180341 diakses pada tanggal 25 Oktober 2020 pukul 16:00 WIB.

${ }^{41}$ Berdasarkan Survei Ekonomi Nasional (Susenas) pada tahun 2015 satu dari emapat anak melakukan pernikahan dini atau sekitar 340.000 anak menikah dibawah usia 18 tahun setiap tahunnya. Berdsarkan data UNICEF pada tahun 2014 perkawinan usia dini di Indonesia merupakan kasus yang tertinggi di kawasan Asia Timur dan Pacifik. Apalagi dalam masa pandemi jumlah pernikahan dini di beberapa daerah mengalami peningkatan seperti di Pengadilan Agama Blitar, Pengadilan Agama Ponorogo, Pengadilan Agama Semarang, Pengadilan Agama Kendal. Gejala Global melonjak dimasa pandemi. Detik.com diakses pada 24 Desember 2020 pukul 17 : 00 WIB.

https://nasional.sindonews.com/read/1228544/15/perkawinan-usia-dini-masih-tinggi1502244235 diakses pada 24 Oktober 2020 pukul 13 : 00 WIB.

42 The Asia Foundation, Citizent'Perception of the Indonesian Justice Sector : Survey Report.,hlm.157.

${ }^{43}$ Pada tahun 2001 perkara cerai gugat sebanyak 93.966 perkara, tahun 2002 sebanyak 94.475 perkara, tahun 2003 sebanyak 88.968 perkara, tahun 2004 sebanyak 97.472 perkara dan tahun 2005 sebnayak 103.383 perkara. Untuk perceraian talakpada 2001 sebanyak 69.767 perkara, tahun 2002 sebanyak 64.165 perkara, tahun 2003 sebanyak 58.225 perkara, tahun 2004 sebanyak 259.930 perkara dan 2005 sebanyak 62.437 perkara. Tim Penyusun MA RI, Naskah Evaluasi dan Analisa Statistik Perkara Msy.P/PTA dan MSY/PA tahun 2001-2005 (Jakarta : MA RI, 2007),hlm 6.
} 
TAHKIM, Jurnal Peradaban dan Hukum Islam. Vol.4 No.l (Maret, 2021) | ISSN : 2597-7962

rasa masih bias gender. Namun demikian perubahan peraturan perkawinan sudah mengalami usaha setidaknya sekarang sudah ada dua draf yang sedang dibahas bersama masyarakat. Satu dari tim Departemen Agama yang merevisi KHI yang kelak akan dijadikan undang undang terapan di Peradilan Agama. Selain itu juga ada draf dari Pengurus Utamaan Gender sebagai pembanding dengan Counter Legal Drafnya (CLD KHI). Pendekatan yang digunakan CLD adalag pluralism, Gender, demokrasi dan HAM juga menggunakan rumusan berdsarkan tujuan-tujuan syariah (maqâsid al-syari'ah)

\section{SIMPULAN}

Kesimpulan dari penelitian ini adalah Efektifitas Undang -undang nomor 16 tahun 2019 tentang perkawinan belumlah efektif. Hal ini terbukti dengan meningkatnya jumlah kasus perkawinan setiap tahunnya seperti nikah usia muda, poligami sampai dengan KDRT. Oleh karena itu perlu adanya pembaruan peraturan perkawinan secara komprehensif . 
TAHKIM, Jurnal Peradaban dan Hukum Islam. Vol.4 No.l (Maret, 202I) | ISSN : 2597-7962

\section{DAFTAR PUSTAKA}

Abdurrahman, Muslan. (2009). Sosiologi dan Metode Penelitian Hukum, Malang : UMM Press.

Ali, Zainuddin. (2011). Filsafat Hukum, Jakarta : Sinar Grafika.

Ahmed An-Naim, Abdullah. (2004). Dekonstruksi Syariah. Penerjemah Ahmed Suedy dan Aminuddin ar-Rani. Yogyakarta: Elkis.

Bakry, Hasbullah. (1981). Kumpulan Lengkap Undang-Undang Perkawinan di Indonesia. Jakarta : Djambatan.

Butt, Simon. (1990). "Polygamy and Mixed Marriage in Indonesia: The Application ofthe Marriage Law in the Courts,' dalam INDONESIA: Law and Society, diedit oleh Timothy Lindsey. NSW.: The Federation Press.

E.K.M. Masinambo. (2003). Antropologi dan Study Hukum, dalam Masinambow,(ed), Hukum dan Kemajemukan Budaya. Jakarta: YOI.

Nakamura, Hisako. (1991). Perceraian Orang Jawa, terj.H.Zaini Ahmad Noeh. Yogyakarta : Gajah Mada University Press.

Nasution, Khoiruddin . (2016). Pengantar Studi Islam. Jakarta : Raja Grafindo Persada.

Mas'udi, Masdar F. 1993. Perempuan di Antara Lembaran Kitab Kuning, dalam Lieas marcoes Natsir dan Johan Hendrik Meuleman, Wanita Islam Indonesia dalam Kajian Tekstual dan Kontekstual. Jakarta, INIS.

Poerwadarminta,W.J.S. (2006). Kamus Umum Bahasa Indonesia, Edisi III, Cet. Ke-3, (Jakarta : Pusat Bahasa Departemen Pendidikan Nasional.

Purnadi Purbacaraka dan Soerjono Soekanto. (1978). Perihal kaidah hukum, Bandung : Citra Aditiya Bhakti.

Raharjo, Sajtipto. (1979). Hukum dan Perubahan Sosial. Bandung: Alumni.

Soekanto, Soerjono. (2012). Faktor - faktor yang Mempengaruhi Penegakan Hukum Cet. Ke-11. Jakarta : Raja Grafindo Persada.

Sudikno Mertokusumo. (1999). Mengenal Hukum (Suatu Pengantar), Yogyakarta : Liberty Yogyakarta.

Supandi,Irfan. (2012). Keajaiban Berumah Tangga. Solo: Tinta Medina. Jakarta: Rineka Cipta.

The Asia Foundation. (2005). Citizent'Perception of the Indonesian Justice Sector : Survey Report. Jakarta : The Asia Foundation. 
TAHKIM, Jurnal Peradaban dan Hukum Islam. Vol.4 No.l (Maret, 202I) | ISSN : 2597-7962

Tim Penyusun MA RI. (2007). Naskah Evaluasi dan Analisa Statistik Perkara Msy.P/PTA dan MSY/PA tahun 2001-2005. Jakarta : MA RI.

Tholabi Kharlie, Ahmad. (2009). Kesadaran Hukum Masyarakat terhadap Terhadap Hukum Perkawinan. Jakarta : Lemit UIN Jakarta dan UIN Press.

Van Bemmelen, Sita. (1987). "The Marriage of Minahasa Women in the Periode 18611933," dalam Indonesian Women in Focus : Past and Present Notions, diedit oleh Elsbeth Locher-Scholten and Anke Niehof . Dordrecht: Foris Publications.

W. Jones, Gavin. (1994). Marriage and Divorce in Islamic Sourh-\&isi Asia (Oxford, Singapore and New York: Oxford University Press.

\section{Jurnal}

Gavin Jones, Yahya Asan dan Tuti Djuartika. (1994). Divorce in West Java, dalam Journal of Comparative Family Studies, Musim Gugur, Vol. 25, No. 3.

Gumilar Rusliwa Somantri. (2005). Memahami Metode Kualitatif. Makara Hubs Asia, Vol. 9.

Mark Cammack, Lawrence A. Young dan Tim B. Keaton. (1997). An Empirical Assessment of Divorce Law in Indonesia," dalam Studia Islamika, Vol. 4, No. 4.

Moh. Zahid. (1994). Dua Dasawarsa Undang-undang Perkawinan, DIALOG. fumai Studi dan informasi keagamaan, Badan Penelitian dan Pengembangan Agama Depag., No. 39, Th. XVIII, Maret.

Musyarrofa Rahmawati dan Hanif Nur Widhiyanti dan Warkum Sumitro. (2018). Efektifitas Pembatasan Usia Perkawinan Berdasarkan Undang-undang Nomor 1 Tahun 1974 tentang Perkawinan, Jurnal Ilmiah Pendidikan Pancasila dan Kewarganegaraan, Vol. 3. hlm.100-105.

Nurlelawati, Euis. Modernization Tradition and Identily : The Kompilasi Hukum Islam and legal Practice in the Indonesian Religion Court.

Nuryamin Aini. (2002). Budaya Hukum : Melintas Batas Formalitas-Yuridis Sentralitas Kompilasi Hukum Islam dan Kitab Kuning dalm putusan Pengadilan Agama, jurnal Ilmiah Ilmu Hukum, Era Hukum, No.3 Tahun 9 Mei.

Ni Luh Ginastini dan Hj. Rina Suwasti. (2019). Efektifitas Undang undang Nomor 1 Tahun 1974 terhadap Perkainan Anak di Bawah Umur (Studi Kasus di Desa Mekarsari Kecamatan Gunungsari Kabupaten Lombok Barat)", Jurnal Gara UNMAS Denpasar, Vol.13. hlm. 326-331.

S. Katz \& Ronald S. Katz. (1978). Legislating Social Change in a Developing Country: The New Indonesian Marriage Law Revised, dalam The American Journal of Comparative Law, Vol.26. 
TAHKIM, Jurnal Peradaban dan Hukum Islam. Vol.4 No.l (Maret, 202I) | ISSN : 2597-7962

Samsidar dan Syamsudin dan Sri Lestari Poernomo. (2019). Efektivitas Pencatatan Perkainan Menurut Undang-undang Nomor 1 Tahun 1974 (Studi di Kapuaten Polewali Mandar), Holrev Faculty of law, Halu Oleo University Kendari, Vol. 3.hlm.116 - 131 .

Triana Sofiani. (2010). Efektifitas Mediasi Perkara Perceraian Pasca Perma Nomor 1 Tahun 2008 di Pengadilan Agama, Jurnal Penelitian IAIN Pekalongan, Vol 7 No 2.

\section{Internet}

Faqihuddin Abdul Kodir dan Ummu Azizah Munaqrkawati, Referensi bagi Hakim Peradilan Agama tentang kekerasan dalam Rumah Tangga (Jakarta : Komnas Perempuan), diakses dari www.komnas perempuan.or.id

Nasarudin Umar,“Refleksi Penerapan Hukum Keluarga di Indonesia,’hlm.2. makalah diakses dari Komnas Perempuan.wwwkomnasperempuan.com

Yulianti Muthmaimah,"Penting,Revisi Undang-Undang Perkawinan”, Komnas Perempuan, 29 Juni 2009. 
TAHKIM, Jurnal Peradaban dan Hukum Islam. Vol.4 No.l (Maret, 202I) | ISSI : 2597-7962 